Biological and Applied Sciences

Vol.60: e17160294, January-December 2017 http://dx.doi.org/10.1590/1678-4324-2017160294 ISSN 1678-4324 Online Edition

\title{
First report of Epibiont ciliates (Ciliophora: Peritrichia) living on larvae of Leptophlebiidae (Ephemeroptera) from Brazil
}

\author{
Daniel Peroni Abrahão ${ }^{1}$ *, José Leonardo Mello ${ }^{1}$, Guilherme Gorni ${ }^{1}$, Juliano José Corbi ${ }^{1}$.
}

${ }^{1}$ Universidade de São Paulo - Escola de Engenharia de São Carlos - Hidráulica e Saneamento, São Carlos, Brasil.

\begin{abstract}
Epibiosis was understood as a commensalism relation between two or more organisms. However, some studies have shown that epibionts can cause deleterious effects to their host. Here, we reported the first report of epibiosis between protozoa Epibiont ciliates (Ciliophora: Peritrichia) living on larvae of Ephemeroptera from Brazil.
\end{abstract}

Key words: epibiosis, Protozoa, Ephemeroptera.

\footnotetext{
*Author for correspondence: daniel.p_a@ @otmail.com
} 
Epibiosis is a facultative association of two organisms: the epibiont and the basibiont. The word "epibiont" comprises organisms that, during the sessile stage of their life cycle, are attached to the surface of a living substratum, while the basibiont lodges and constitutes a support ${ }^{1,2,3}$. Numerous species of protozoa belonging to the group of peritrich Ciliophora can be found living in other aquatic organisms. As pointed to by ${ }^{3}$, because of epibiosis, the host and the epibiont have beneficial and negative aspects. The negative effects of epibiosis on the host may involve, for example, a decrease in survival capability and perturbation of movement ${ }^{4}$. Epibiosis is beneficial for epibiont protozoa, which can be transported to regions richer in food or to much more oxygenated places, as pointed out by ${ }^{5}$. As pointed by following works ${ }^{6}$, peritrichs are a diverse, ecologically important ciliate group usually with a complex life cycle.

Several ciliate protozoans live as epibionts on animals and plants, using them as ${ }^{1}$. Most ciliates, for example, of the genus Rhabdostyla Kent, 1880 (Peritrichia, Epistylidae), live as epibionts of freshwater invertebrates, such as rotifers, crustaceans (Cladocerans, Copepods), insects from the orders Ephemeroptera and Diptera (Chironomidae), and annelids (Oligochaeta and Polychaeta) ${ }^{1}$. Along these lines 5 , found Rhabdostyla sp. and Scyphidia sp. living on copepods ${ }^{2}$, points to epibionts living on custraceans ${ }^{1}$ found Rhabdostyla chironomi inhabiting the Chironomidae larvae ventral tubles ${ }^{7}$, that found the occurrence of peritrich ciliates on the limnic oligochaete Limnodrilus hoffmeisteri and ${ }^{8}$ that points the occurrence of Epistylis sp. (Ciliophora: Peritrichia) living on nymphs of Kempnyia (Plecoptera). It is also known that Ciliophora can cause problems in niloticus rearing (Oreochromis niloticus) ${ }^{9}$ and that these situations play an important ecological role in freshwater ecosystems, but much of the work described is morphological and taxonomic aspects ${ }^{10}$.Within the Ephemeroptera (Insecta), there is a description of nymphs parasitized by nematodes, where they can cause damage such as infertility and male larvae developing feminine appearance as pointed by reference ${ }^{11}$.

Here, we report a first record of epibiont ciliates (Ciliophora: Peritrichia) living on larvae of Leptophlebiidae (Ephemeroptera), from Brazil (see Figure 1). The organisms were collected in September 2015, from the Monjolinho Reservoir, using a "D" aquatic net $(0,25 \mathrm{~mm}$ of mesh size $)$ by the kick sampling method, during a survey of benthic macroinvertebrates. Organisms were separated on illuminated tray and fixed in $70 \%$ alcohol. The Ephemeroptera were identified using the identification key ${ }^{12,13}$ and the epibionts ciliates were identified using ${ }^{14}$. The Monjolinho reservoir is located in the campus of the Federal University of São Carlos (São Paulo, Brazil) in a subtropical region $\left(47^{\circ} 53^{\prime} \mathrm{W}\right.$ and $\left.22^{\circ} 01^{\prime} \mathrm{S}\right)$.

The epibiont ciliates were found usually located on the head and on the pronotum and mesonotum (thorax) (see Figure 1). The presence of epibionts generally on the head and on the pronotum and mesonotum (thorax) of the Ephemeroptera can bring some feed difficulties for these aquatic organism. On the other hand, as pointed by work ${ }^{4}$ peritrichs primarily consume bacteria, their location on the body of the host is indifferent.

As pointed by ${ }^{5}$ consider that bigger organisms are easier targets for the epibionts than smaller ones. Consequently, our observations may be related to epibiont preference for these aquatic organisms or to the presence of a comparatively larger adhesion surface offered by each Odonata individual.

\section{ACKNOWLEDGEMENTS}

We would like to thank the LEAA laboratory team (USP) and the department of Hydraulic and Sanitation (SHS). 


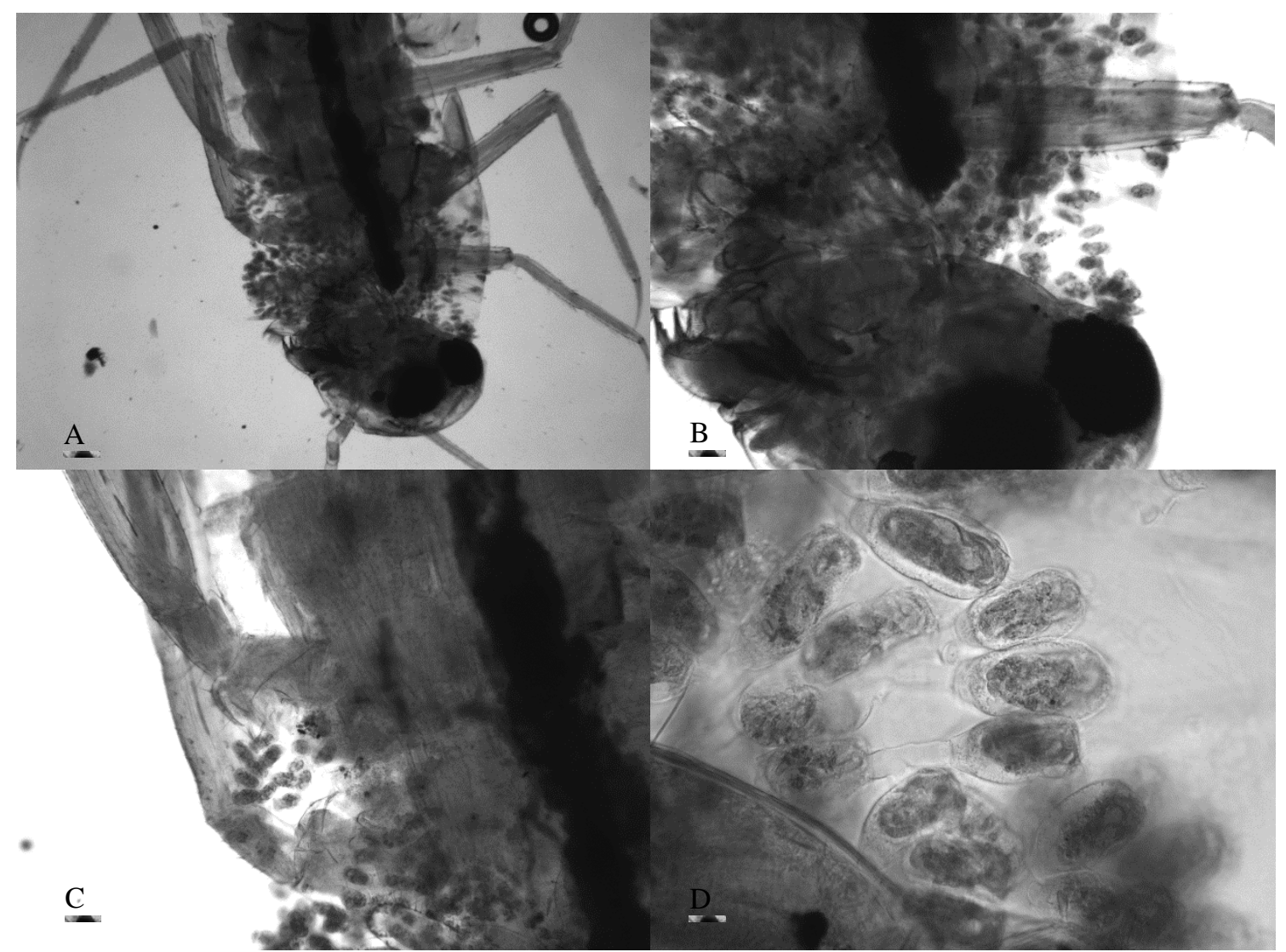

Figure 1. A. Leptophlebiidae (Ephemeroptera) with Epibiont ciliates (Protozoa: Ciliophora) (zoom 4x); B. Zoom in Epibiont ciliates (Ciliophora:Peritrichia) on the dorsal side Leptophlebiidae (Ephemeroptera) (zoom 10x); C. Epibiont ciliates (Ciliophora:Peritrichia) (zoom 10x); D. Epibiont ciliates (Ciliophora:Peritrichia) (zoom 40x).

\section{REFERENCES}

1- Dias RJP, Cabral AF, Stephan NNC, Martins RT, Silva-Neto ID, Alves RG, D’agosto MA. Record of Rhabdostyla chironomi Kahl, 1933 (Ciliophora, Peritrichia) Epibiont on Chironomidae larvae (Diptera, Chironomidae) in a lotic system in Brazil. Brazilian Journal of Biology. 2007; 67(4), p.783-785.

2-Fernandez-Leborans G, Tato-Porto ML. A review of the species of Protozoan Epibionts on Crustaceans.I. Peritrichciliates. Crustaceana. 2000; 73(6), p. 643-683.

3-Wahl, M. Marine Epibiosis. I. Fouling and antifouling some basic aspects. Marine Ecology Progress Series. 1989; 58, p.175-189.

4-Henebry MS, Ridgeway BT. Epizoic ciliated protozoa of planktonic Copepods and Cladocerans and their possible use as indicators of organic pollution. Transactions of the American Microscopical Society. 1979; 98(4), p. 495-508.

5-Regali-Seleghim MH, Godinho MJL. Peritrichepibiont protozoans in the zooplankton of a subtropical shallow aquatic ecosystem (Monjolinho Reservoir, São Carlos, Brazil). J. Plankton Res. 2004; 26(5), p.501-508.

6-Liu X and Gong J. Revealing the Diversity and Quantity of Peritrich Ciliates in Environmental Samples Using Specific Primer-based PCR and Quantitative PCR. Microbes Environment. 2012; 27(4), p.497-503.

7-Dias RJP, Cabral AF, Martins RT, Stephan NNC, Silva-Neto ID, Alves RG and D'Agosto M. Occurrence of peritrich ciliates on the limnic oligochaete Limnodrilus hoffmeisteri (Oligochaeta, Tubificidae) in the neotropics. Journal of Natural History.2009; 43(1-2), p.115.

8-Dias RJP, Silva - Neto ID and Costa JM. Sítio de localização de protistas ciliados peritríquios (Ciliophora: Peritrichia) epibiontes sobre ninfas de Kempnyia Klapálek, 1914 
(Insecta: Plecoptera: Perlidae). 2009. Anais do IX Congresso de Ecologia do Brasil, 13 a 17 de setembro, São Lourenço - MG.

9-Zanolo R, Yamamura, MH. Parasitas em tilápias-do-nilo criadas em sistema de tanques-rede. Semina: Ciências Agrárias. 2006; 27(2), p.281-288.

10-Dias RJP, D’ávila S, Wieloch AH, D'agosto M. Protozoan ciliate epibionts on the freshwater apple snail Pomaceafigulinain a urban stream of south-east. Brazil Journal of Natural History. 2008; 42, p. 1409-1420.

11-Pritchard G, Zloty J. Life histories of two Ameletus mayflies (Ephemeroptera) in two mountain streams: the influence of temperature, body size, and parasitism. Journal of the North American Benthological Society. 1994; p.557-568.

12-Hamada N, Nessimian JL, Querino RB. Insetos aquáticos na Amazônia brasileira: taxonomia, biologia e ecologia. Embrapa Meio-Norte-Livros cie. 2014.

13-Mugnai R, Nessimian JL, Baptista DF. Manual de identificação de macroinvertebrados aquáticos do estado do Rio de Janeiro. Technical Books Editora, Rio de Janeiro. 2010.

14-Foissner W, Berger H. 1996. A user-friendly guide to ciliates (Protozoa, Ciliophora) commonly used by hydrobiologists as bioindicators in rivers, lakes, and waste waters, with notes on their ecology. Freshwater Biol. 35:375-498. 